\title{
Hubungan antara Ekspresi Gambar Orang dan Faktor-Faktor Kepribadian 16PF
}

\author{
Reni Nurhayati \\ Agung Santoso \\ Program Studi Psikologi, Fakultas Psikologi Universitas Sanata Dharma, Yogyakarta
}

\begin{abstract}
This study aims to determine how the dimensions of Draw A Person test (DAP) is able to uncover traits from the $16 \mathrm{PF}$ test (The Sixteen Personality Factor Questionnaire). Data from 200 subject who filled the DAP and 16 PF tests were processed and analyzed using exploratory factor analysis and regression. From the analysis of factor analysis to people's image expression data, we obtained 8 sets of factors, namely Factor I - VIII from DAP. From the regression test between Factor $16 \mathrm{PF}$ and the factor image test of the person, it was found several Factors $16 \mathrm{PF}$ which can be used to predict some expressions of people's images. These factors include Factor $\mathrm{Q}_{3}$ which is able to predict Factor VII and Factor $\mathrm{Q}_{4}$ that is able to predict Factor I.
\end{abstract}

Keywords: 16 PF, DAP, expressions of people's image, personality test

Abstrak. Penelitian ini bertujuan untuk mengetahui seberapa besar dimensi-dimensi penilaian tes ekspresi gambar orang (DAP/Draw A Person) mampu mengungkap traits dari tes 16 PF (The Sixteen Personality Factor Questionnaire). Sebanyak 200 data subjek yang berasal dari tes DAP dan 16 PF diolah dan dianalisis menggunakan analisis faktor eksploratori dan regresi. Dari pengujian analisis faktor terhadap data ekspresi gambar orang didapatkan 8 kumpulan faktor yaitu Faktor I - VIII dari DAP. Dari pengujian regresi antara Faktor 16 PF dengan Faktor tes gambar orang, didapatkan beberapa Faktor 16 PF yang dapat digunakan untuk memprediksi beberapa ekspresi gambar orang. Faktor tersebut antara lain adalah Faktor $Q_{3}$ yang mampu memprediksi Faktor VII dan Faktor $\mathrm{Q}_{4}$ yang mampu memprediksi Faktor I.

Kata kunci: 16 PF, DAP, ekspresi gambar orang, tes kepribadian

Korespondensi: Reni Nurhayati. E-mail: reni_rere89@yahoo.co.id. 
Tes grafis saat ini masih banyak digunakan sebagai alat asesmen kepribadian di Indonesia. Salah satu jenis tes grafis yang peka terhadap kecenderungan kepribadian seseorang secara personal adalah tes DAP (Draw A Person) (Etikawati, komunikasi pribadi, 10 Mei 2010). Baum misalnya, hanya mengungkap fungsi okupasi individu dan tes House Tree Person (HTP) yang hanya mengungkap tentang pola keluarga individu. Dapat disimpulkan bahwa DAP memiliki kemam-puan menyeluruh untuk melihat bagaimana subjek menghadapi stimulus yang ada di hadapannya dan di sekitarnya (Hooker \& McAdams, 2003). Menurut Machover, DAP juga mampu mengungkap beberapa hal yang terkait dengan subjek secara spesifik, antara lain umur, sekolah, ambisi, karakteristik kepribadian, kehidupan serta perilaku di dalam kehidupan keluarga pada subjek yang menggambar (Groth-Marnat \& Robert, 1984). Melengkapi pernyataan Machover, Sidney Levy menambahi bahwa DAP juga dianggap mampu mengungkap simbol ekspresi atau ekspresi yang dituangkan subyek pada hasil gambarannya (Edwin \& Bellak, 1950).

Tes grafis memiliki beberapa kelemahan yang dapat menggangu validitas penggunaannya. Kelemahan yang pertama adalah hasil tes grafis yang didapatkan sangat tergantung pada situasi psikologis subjek. Misalnya tes grafis diberikan pada subjek yang sedang mengalami masalah, maka hasil tes yang dapat dibaca adalah bagian pola subjek sewaktu menghadapi masalah dan bukan merupakan pola kepribadian yang utuh pada subjek. Jika masalah yang kedua ini diinterpretasi oleh orang belum memiliki pengalaman dan belum memiliki jam terbang yang tinggi, dikhawatirkan akan menghasilkan interpretasi yang bersifat hanya membaca subjek pada saat itu saja tanpa memperhatikan kondisi subjek yang sesungguhnya (Etikawati, komunikasi pribadi, 10 Mei 2010). Kelemahan yang kedua adalah tes ini bersifat subjektif, sehingga jika hasil tes ini diinterpretasi oleh orang yang belum banyak memiliki jam terbang dan belum banyak memiliki pengalaman dalam menginterpretasi tes grafis maka hasilnya akan menjadi kurang valid (Groth-Marnat \& Robert, 1984).

Berdasarkan kelemahan tersebut, maka perlu dilakukan penelitian untuk memberi alternatif metode pemberian skor pada DAP. Alternatif ini diharapkan dapat mengisi objektivitas penilaian untuk DAP. Penilaian ini dilakukan dengan cara menggunakan ekspresi gambar pada DAP untuk mengungkap traits atau sifat pada seseorang (Hooker \& McAdams, 2003). Ekspresi gambar tersebut didapat dari melihat dan menginterpretasi dimensi DAP. Konsep-konsep yang mendasari teknik-teknik analisis gambar DAP dikembangkan dengan cara meneliti ribuan 
gambar dalam konteks klinis. Metodenya menggunakan metode proyektif dari analisis kepribadian dan teori psikoanalisa. Secara garis besar, prinsip-prinsip pada analisis gambar dibuat berdasarkan penelitian mengenai tipe-tipe klinis. Dimana ciri-ciri grafis pada tipe klinis tertentu mendapat penekanan. Langkah pelaksanaanya dengan cara mengumpulkan gambar-gambar yang telah ada, kemudian dicatat secara terperinci meliputi data pribadi dan riwayat klinis serta digunakan untuk meneliti ciri-ciri grafis tertentu (Machover,1965). Prinsip dasar dalam menginterpretasi DAP adalah dengan memperhatikan dimensi-dimensi yang ada pada gambar subjek. Hal ini dikarenakan masing-masing dimensi DAP memiliki arti yang akan mempengaruhi hasil interpretasi gambar subjek.

Figur yang digambar adalah orang yang bersangkutan dan kertas diibaratkan sebagai lingkungannya. Proses menggambar figur manusia untuk subjek, baik disadari maupun tidak disasari merupakan suatu masalah yang diproyeksikan diri ke dalam semua arti tubuh dan sikap yang ditampilkan dalam gambaran tubuh pada gambar subjek. Dengan kata lain, figur ini merupakan suatu gambaran pada individu yang menggambarnya (Machover, 1965).

DAP memiliki beberapa dimensi yang digunakan untuk menginterpretasi gambar. Dimensi yang pertama adalah dimensi berdasarkan eksekusi, meliputi penempatan gambar, ukuran figur, tipe garis, hapusan yang ada pada gambar, dan shading pada gambar. Dimensi yang kedua adalah dimensi berdasarkan fungsional, meliputi ukuran kepala, keadaan rambut, keadaan alis, keadaan mata, ukuran telinga, ukuran hidung, bentuk mulut, ukuran leher, ukuran lengan, ukuran tangan, bentuk jari tangan, ukuran kaki, dan keadaan jari kaki (Machover, 1965).

Kekurangan tes DAP di antaranya yang pertama, jika tes ini dipegang oleh penginterpretasi yang kurang memiliki pengalaman serta jam terbang yang tinggi dalam menggunakan tes ini, maka hasil interpretasinya kurang valid. Hal ini dikarenakan hasil interpretasi yang didapatkan kurang sensitif dalam menangkap hal yang ada pada gambar tersebut. Kekurangan yang kedua adalah sangat tergantung pada situasi psikologis pada saat seseorang itu menggambar (Etikawati, Wawancara 1).

Tes ini juga memiliki kelebihan. Kelebihan yang pertama, tes ini dapat terhindar dari faking karena manusia itu akan cenderung menggambar gambaran sesuai bawaan kepribadian mereka masingmasing. Kepribadian antar individu itu berbeda satu dengan yang lain. Kelebihan yang kedua adalah jika gambar dipegang oleh penginterpretasi yang sudah memiliki banyak pengalaman serta jam terbang yang tinggi, maka hasil gambar valid. Hal ini 
dikarenakan penginterpretasi cukup sensitif dalam menginterpretasi gambar (Etikawati, Wawancara 1).

Tes kepribadian yang akan digunakan untuk membandingkan dengan tes DAP adalah 16 PF (The Sixteen Personality Factor Questionnaire). Ada beberapa keunggulan yang dimiliki $16 \mathrm{PF}$. Keunggulan yang pertama, 16 PF memiliki construct validity yang tinggi. Salah satu contoh pembuktian ini adalah dengan adanya hubungan yang kuat dari hasil penelitian yang dilakukan Boyle (1989) yang mempelajari hubungan antara $16 \mathrm{PF}$ dan skala Cattel, Comrey, dan Eysenck, kemudian penelitian yang dilakukan Dancer dan Woods (2007) dengan menghubungkan skala $16 \mathrm{PF}$ dan FIRO-B, dan beberapa penelitian yang dilakukan oleh Carnivez dan Allen (2005), Cattell (1996), Conn dan Rieke (1994) serta Gerbing dan Tuley (1991) yang menghubungkan antara skala $16 \mathrm{PF}$ dan skala NEO-PI. Keunggulan yang kedua, 16 PF memiliki factorial validity yang baik. Satu hal yang penting mengenai sumber validitas dari pertanyaan $16 \mathrm{PF}$ adalah adanya study factor-analytic mengenai sifat dasar dan umum pada bermacam-macam sampel orang (Boyle, 1989; Carnivez and Allen, 2005; Cattell, 1996). Hasil penelitian yang dilakukan Hofer dan kawan-kawan menguatkan analisis faktor dan persamaan structural modeling tes pada factorial invariance untuk mempelajari pengukuran yang ada pada keberagaman, dan dapat disimpulkan bahwa struktur faktor pada 16 PF terucap baik pada sampel orang yang berbeda, antar gender, dan antar perbedaan form pada 16 PF (Boyle, 2004).

$16 \mathrm{PF}$ adalah alat asesmen kepribadian yang meliputi rentang ukuran normal kepribadian (Cattel, 1957, 1973). Cattel mengusulkan sebuah multi-level, struktur hierarki kepribadian, yaitu ukuran global yang melukiskan kepribadian yang luas, yang secara konseptual lebih dari faktor primer, yang menyatakan detail yang bagus dan perbedaan yang sangat sedikit membuat orang lain menjadi unik, dan lebih kuat dalam memprediksi perilaku yang aktual (Boyle, 2004).

Faktor A dalam 16 PF terdiri dari dua skor yaitu skor yang rendah disebut Sizothymia (A-) dan skor yang tinggi disebut Affectothymia (A+). Pada Sizothymia (A-) ada beberapa karakteristik yang tergolong di dalamnya, antara lain suka mengkritik, selalu berpandangan pada ide yang dimiliki, suka bekerja sendiri, memiliki pendekatan intelektual yang keras, dan tidak menyukai kompromi. Reserver, detached, critical, aloof, dan stiff merupakan karakteristik yang tertera di lembar grafik 16 PF (Cattel, dkk., 1970). Karakteristik yang tergolong di dalam Affectothymia (A+) antara lain suka bergabung di dalam kegiatan kelompok, suka berhubungan dengan orang lain, tidak suka mengkritik, mampu mengingat nama orang, sedikit tergantung pada ketelitian kerja dan lebih senang melakukan 
perjumpaan "sambil lalu". Warmhearted, outgoing, easygoing, dan participating merupakan karakteristik yang tertera di lembar grafik 16 PF (Cattel, dkk., 1970).

Faktor B yang terdiri dari skor yang rendah, yaitu Low Intelligence (B-) dan skor yang tinggi, yaitu High Intelligence (B+). Low Intelligence (B-) memiliki beberapa karakteristik yang tergolong di dalamnya, antara lain kapasitas mental yang rendah, tidak mampu menye-lesaikan permasalahan abstrak, kurang baik dalam pengaturan atau pengorganisasian, tidak mampu mempertimbangkan sesuatu, moril rendah, dan berhenti berusaha. Crystallized, power measure, dan dull merupakan karakteristik yang tertera di lembar grafik 16 PF (Cattel, dkk., 1970). Karakteristik yang berada di High Intelligence $(\mathrm{B}+)$, antara lain kapasitas mental secara umum tergolong tinggi, memiliki wawasan yang banyak, mampu mempertimbangkan dengan baik, moril tinggi, dan tekun. Crystallized, power measure, dan bright merupakan karakteristik yang tertera di lembar grafik 16 PF (Cattel, dkk., 1970).

Faktor C terdiri dari skor yang rendah disebut Emotional Instability atau Ego Weakness (C-) dan Higher Ego Strength $(\mathrm{C}+)$. Ada beberapa karakteristik yang tergolong di dalam Emotional Instability atau Ego Weakness (C-) antara lain mudah tersing-gung yang dikarenakan sesuatu maupun seseorang, merasa tidak puas dengan suatu situasi, yakni situasi keluarganya, pemba-tasan dalam hidupnya, serta kesehatannya, dan merasa tidak mampu mengatasi hidupnya. Affected by feelings, emotionally less stable, easily upset, dan changeable merupakan karakteristik yang tertera di lembar grafik 16 PF (Cattel, dkk., 1970). Higher Ego Strength (C+) terdapat beberapa karakteristik yang berada di dalamnya, antara lain emosi yang dimiliki sudah masak, tenang, tidak mudah emosi (lebih melihat situasi realita dan fakta terlebih dahulu), dan mengendalikan dalam menghadapi kesuli-tan. Emotionally stable, mature, faces reality, dan calm merupakan karakteristik yang tertera di lembar grafik 16 PF (Cattel, dkk., 1970).

Faktor D adalah faktor yang sumber sifatnya jelas pada anak-anak, serta sedikit berbeda pada remaja dan secara konsekuen dimasukkan pada childhood personality scales tetapi tidak berada di 16 PF dikarenakan terjadi di HSPQ. Faktor ini terdiri dari dua skor yaitu skor yang rendah, disebut Phlegmatic Temprament (D) dan skor yang tinggi, yakni disebut Excitability (D+). Karakteristik yang tergolong di dalam Phlegmatic Temprament (D-) antara lain mampu menahan nafsu, puas terhadap diri sendiri, tenang serta hati-hati, tidak mudah iri hati, dan tidak mudah gelisah (Cattel, dkk., 1970). Karakteristik yang terdapat pada Excitability (D+) antara lain gelisah tidur, mudah terganggu dari kerja; kebisingan; kesulitan yang hakiki, terluka serta marah 
jika tidak diberikan posisi penting, dan mudah bereaksi secara emosional (Cattel, dkk., 1970).

Faktor E terdiri dari dua skor, antara lain skor yang rendah yaitu Submissiveness (E-) dan skor yang tinggi, yaitu Ascendance (E+). Submissiveness (E-) terdiri dari beberapa karakteristik, antara lain patuh, bergantung, penuh perhatian, ekspresif, mampu menyesuaikan diri, dan rendah hati. Obedient, mild, easily led, docile, dan accomodating merupakan karakteristik yang tertera di lembar grafik 16 PF (Cattel, dkk., 1970). Ascendance (E+) terdiri dari beberapa karakteristik, antara lain assertif, tidak tergantung, bersungguh-sungguh, dan suka menentang. Assertive, aggressive, competitive dan stubborn merupakan karakteristik yang tertera di lembar grafik 16 PF (Cattel, dkk., 1970).

Faktor F memiliki skor yang rendah, disebut dengan Desurgency (F-) dan skor yang tinggi, yaitu Surgency (F+). Desurgency (F-) memiliki beberapa karakteristik yang berada di dalamnya, antara lain pendiam, oang yang fokus, tidak komunikatif, dan orang yang suka berhati-hati serta cenderung lambat. Sober, taciturn, dan serious merupakan karakteristik yang tertera di lembar grafik 16 PF (Cattel, dkk., 1970). Beberapa karakteristik yang tergolong di dalam Surgency $(\mathrm{F}+)$, antara lain senang bicara, senang bersorak, cenderung ekspresif, cenderung siap siaga, dan tangkas. Enthusiastic, heedless, dan happy-go-luck merupakan karakteristik yang tertera di lembar grafik 16 PF (Cattel, dkk., 1970).

Faktor G terdiri dari skor yang rendah, disebut dengan Low Superego Strength atau Lack of Acceptance of Group Moral Standards (G-) dan skor yang tinggi, yaitu Superego Strength atau Character $(\mathrm{G}+)$. Mudah berubah-ubah, mudah berhenti berusaha, cenderung ceroboh, kurang memiliki semangat yang kuat, acuh pada orang lain, dan sabar pada diri sendiri merupakan beberapa karak-teristik yang berada di dalam Low Superego Strength atau Lack of Acceptance of Group Moral Standards (G-). Disregards rules dan expedient merupakan karakteristik yang tertera di lembar grafik 16 PF (Cattel, dkk., 1970). Beberapa karakteristik yang tergolong di dalam skor yang tinggi, yaitu Superego Strength atau Character (G+), antara lain cenderung tekun serta gigih, bertanggung jawab, disiplin dalam emosional, konsisten, cenderung berhatihati serta teliti, dan memperhatikan standar moral dan peraturan yang ada. Conscientious, persistent, moralistic, dan staid merupakan karakteristik yang tertera di lembar grafik 16 PF (Cattel, dkk., 1970).

Faktor $\mathrm{H}$ terdiri dari skor yang rendah, yakni disebut Threctia (H-) dan skor yang tinggi, yaitu Parmia $(\mathrm{H}+)$. Beberapa karakteristik yang tergolong pada Threctia (H-), antara lain sangat pemalu, merasa sakit hati jika merasa dianggap 
kurang bermutu, pelan serta kurang tegas, kurang menyukai kontak sosial, lebih memilih memiliki satu sedikit teman dekat daripada berkumpul dalam kelompok besar, dan tidak mampu menjaga kontak dengan semua yang ada di sekitarnya. Shy, timid, restrained, dan threat-sensitive merupakan karakteristik yang tertera di lembar grafik 16 PF (Cattel, dkk., 1970). Parmia $(\mathrm{H}+)$ memiliki beberapa karakteristik, antara lain merasa bebas untuk ikut berpartisipasi, menyukai keramahan, suka bertemu dengan orang, periang, dan aktif. Adventurous, "thickskinned," dan socially bold merupakan karakteristik yang tertera di lembar grafik 16 PF (Cattel, dkk., 1970).

Faktor I terdiri dari skor yang rendah, yakni disebut Harria (I-) dan skor yang tinggi, yaitu Premsia (I+). Harria (I-) memiliki beberapa karakteristik, antara lain maskulin, menyukai hal-hal yang praktis, cenderung dewasa, memiliki solidaritas kelompok, dan realistis. Thought-minded dan rejects Illusions merupakan karakteristik yang tertera di lembar grafik 16 PF (Cattel, dkk., 1970). Beberapa karakteristik yang berada pada Premsia $(\mathrm{I}+)$, antara lain menyukai perjalanan serta pengalaman, cenderung labil, kurang realistis, imaginatif, dan menyukai hal yang dramatis. Tender-minded, sensitive, dependent, dan overprotected merupakan karakteristik yang tertera di lembar grafik 16 PF (Cattel, dkk., 1970).
Skor yang rendah, yakni disebut Zeppia (J-) dan skor yang tinggi, yaitu Coasthenia (J+) merupakan bagian dari Faktor J. Zeppia (J-) memiliki beberapa karakteristik, antara lain senang berada di dalam kelompok, senang memperhatikan, penuh semangat, dan menerima keadaan standar yang biasa (Cattel, dkk., 1970). Coasthenia (J+) memiliki karakteristik, antara lain cenderung memikirkan kesalahnnya serta bagaimana menghindari masalah tersebut, memelihara rasa lelah ketika bangun di pagi hari, cenderung curang, dan memperlihatkan kepribadian yang berbeda ketika berada di dalam keolompok. Faktor J merupakan faktor yang tidak dimasukkan ke dalam skala 16 PF tetapi faktor ini penting di dalam HSPQ. Faktor ini melengkapi deskripsi dari sumber sifat primer. Penelitian membuktikan satu dari beberapa pola sulit untuk diinterpretasikan dari sifatnya (Cattel, dkk., 1970).

Faktor L memiliki dua skor, antara lain skor yang rendah, yakni disebut Alaxia (L-) dan skor yang tinggi, yaitu Protension $(\mathrm{L}+)$. Tidak memiliki ambisi serta tidak bekerja keras, mudah berubah, siap untuk melupakan kesulitan, suka memberi toleransi serta pemahaman, dan tidak menaruh curiga, merupakan beberapa karakteristik yang dimiliki Alaxia (L-). Trusting, accepting, dan conditions merupakan karakteristik yang tertera di lembar grafik 16 PF (Cattel, dkk., 1970). 
Protension (L+) juga memiliki beberapa karakteristik, antara lain senang dengan hal yang berkitan dengan dogma, cenderung curiga pada gangguan, senang diam ketika mengalami frustasi, dan kejam. Suspecting dan jealous merupakan karakteristik yang tertera di lembar grafik 16 PF (Cattel, dkk., 1970).

Skor yang rendah, yakni disebut Praxernia (M-) dan skor yang tinggi, yaitu Autia $(\mathrm{M}+)$ adalah skor yang dimiliki Faktor M. Praxernia (M-) memiliki beberapa karakteristik, antara lain menyukai hal yang praktis, fokus pada hasil, mudah bosan, menyukai hal yang realistis, dan bersungguh-sungguh. Practical dan has "down to earth" concerns merupakan karakteristik yang tertera di lembar grafik 16 PF (Cattel, dkk., 1970). Autia (M+) memiliki beberapa karakteristik, antara lain memiliki ide, tertarik dengan seni, teori, dasar keprcayaan, imaginatif, dan memiliki fantasi dari pendapat praktis. Imaginative dan absent-minded merupakan karakteristik yang tertera di lembar grafik 16 PF (Cattel, dkk., 1970).

Faktor N memiliki dua skor yaitu skor yang rendah, biasa disebut Naivete $(\mathrm{N}-$ ) dan skor yang tinggi, yaitu Shrewdness $(\mathrm{N}+)$. Naivete $(\mathrm{N}-)$ memiliki beberapa karakteristik, antara lain kagok pada dunia sosial, orang yang tidak begitu jelas, emosionalnya hangat, spontan serta natural, memiliki selera yang sederhana, kurang memiliki insight diri, dan kurang terampil dalam menganalisis suatu sebab. Forthright dan unpretentious merupakan karakteristik yang tertera di lembar grafik 16 PF (Cattel, dkk., 1970). Pada Shrewdness $(\mathrm{N}+)$ terdapat beberapa karakteristik, antara lain memiliki dasar sosial, menyukai hal yang berkaitan dengan hal eksak (misalnya berhitung), pengertian terhadap diri sendiri maupun dengan orang lain, ambisius, tegas, dan pandai. Astute dan worldly merupakan karakteristik yang tertera di lembar grafik 16 PF (Cattel, dkk., 1970).

Skor yang rendah, disebut dengan Unstroubled Adequacy (O-) dan skor yang tinggi, yaitu Guilt Proneness (O+) merupakan bagian dari Faktor 0 . Unstroubled Adequacy (0-) memiliki beberapa karakteristik, antara lain percaya pada diri sendiri, ulet serta tabah, cenderung tenang, bijaksana, tidak begitu terbuka, cenderung kurang sopan, dan tidak mudah khawatir. Self-assured, placid, secure, dan complacent merupakan karakteristik yang tertera di lembar grafik 16 PF (Cattel, dkk., 1970). Pada Guilt Proneness (0+) memiliki beberapa karakteristik, antara lain mudah khawatir, mudah tertekan, mudah tersentuh, memiliki pengertian yang kuat pada orang lain, cermat, dan cenderung suka sendiri. Apprehensive, self-reproaching, insecure, worrying, dan troubled merupakan karakteristik yang tertera di lembar grafik 16 PF (Cattel, dkk., 1970). 
Faktor Q merupakan faktor yang tidak terlihat di dalam perilaku dan mungkin dapat diketahui banyak mengalami "mental interior" atau mental dalam, dimana peletakkannya di luar nilai subjek pada respon pertanyaan. Faktor $\mathrm{Q}_{1}$ memiliki dua skore, yaitu skor yang rendah, disebut dengan Conservatism of Temperament $\left(\mathrm{Q}_{1^{-}}\right)$dan skor yang tinggi, yaitu Radicalism $\left(\mathrm{Q}_{1}+\right)$. Conservatism of Temprament $\left(\mathrm{Q}_{1^{-}}\right)$memiliki beberapa karakteristik, antara lain suka dengan hal yang berhubungan dengan hemat, menghormati suatu ide, dan sulit untuk bertoleransi. Conservative, respecting established ideas, dan tolerant of traditional difficulties merupakan karakteristik yang tertera di lembar grafik 16 PF (Cattel, dkk., 1970). Radicalism $\left(\mathrm{Q}_{1}+\right)$ memiliki beberapa karakteristik, antara lain suka hal yang berhubungan dengan eksperimen serta percobaan, liberal, suka menganalisis, dan suka berpikir bebas. Experimenting, liberal, analytical, dan free-thinking merupakan karakteristik yang tertera di lembar grafik 16 PF (Cattel, dkk., 1970).

Faktor $\mathrm{Q}_{2}$ memiliki dua skor, antara lain skor yang rendah, yaitu Group Dependency $\left(\mathrm{Q}_{2}-\right)$ dan skor yang tinggi, yaitu disebut Self-Sufficiency $\left(\mathrm{Q}_{2}+\right)$. Group Dependency $\left(\mathrm{Q}_{2}-\right)$ memiliki beberapa karakteristik, antara lain senang hidup di dalam kelompok, tergantung pada izin sosial, dan mengikuti kebiasaan adat. Sociably group dependent dan A "joiner" dan sound follower merupakan karakteristik yang tertera di lembar grafik 16 PF (Cattel, dkk., 1970). Pada Self-Sufficiency $\left(Q_{2}+\right)$ memiliki beberapa karakteristik, antara lain lebih senang mengambil keputusan dan senang menjadi sumber. Self-sufficient, resourceful, dan prefers own decisions merupakan karakteristik yang tertera di lembar grafik 16 PF (Cattel, dkk., 1970).

Faktor $\mathrm{Q}_{3}$ memiliki dua skor, antara lain skor yang rendah, yakni disebut Low Self-Sentiment Integration $\left(\mathrm{Q}_{3}-\right)$ dan skor yang tinggi, yaitu High Strength of SelfSentiment $\left(\mathrm{Q}_{3}+\right)$. Low Self-Sentiment Integration $\left(\mathrm{Q}_{3}{ }^{-}\right)$terdiri dari beberapa karakteristik, antara lain kurang terkontrol, mengikuti dorongan, dan kurang terbuka pada peraturan sosial. Uncontrolled, lax, follows own urges, dan careless of social rules merupakan karakteristik yang tertera di lembar grafik 16 PF (Cattel, dkk., 1970). High Strength of Self-Sentiment $\left(\mathrm{Q}_{3}{ }^{+}\right)$ memiliki beberapa karakteristik, antara lain setuju pada karakter respon sosial, memiliki kontrol diri, tekun, memiliki pemikiran ke masa depan, penuh perhatian dengan orang lain, teliti, dan menghormati tata cara serta reputasi sosial. Controlled, exacting, will power, socially precise, compulsive, dan following self-image merupakan karakteristik yang tertera di lembar grafik 16 PF (Cattel, dkk., 1970).

Skor yang rendah, yakni disebut Low Ergic Tension $\left(\mathrm{Q}_{4}{ }^{-}\right)$dan skor yang tinggi, yaitu High Ergic Tension $\left(\mathrm{Q}_{4}+\right)$ 
merupakan skor yang ada pada Faktor $\mathrm{Q}_{4}$. Cenderung santai, tenang, cenderung lamban, kurang melakukan pencegahan, dan senang menyusun sesuatu merupakan beberapa karakter yang dimiliki Low Ergic

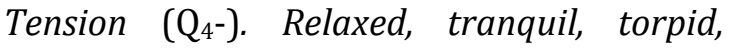
unfrustrated, dan composed merupakan karakteristik yang tertera di lembar grafik 16 PF (Cattel, dkk., 1970). High Ergic Tension $\left(\mathrm{Q}_{4}{ }^{+}\right)$memiliki beberapa karakteristik, antara lain cenderung senang melakukan pencegahan, mampu menggerakkan, terlalu mudah lelah, dan cenderung suka bertingkah. Tense, frustrated, driven, overwrought, dan fretful merupakan karakteristik yang tertera di lembar grafik 16 PF (Cattel, dkk., 1970).

Pada penelitian ini masing-masing dimensi DAP akan dikorelasikan dengan masing-masing faktor yang ada pada $16 \mathrm{PF}$. Semakin besar korelasi yang terjadi antara dimensi yang telah ditemukan pada DAP dan item yang ada di dalam 16 PF, maka dimensi tersebut dapat digunakan sebagai standard dimensi untuk tes DAP. Standard dimensi ini diharapkan dapat digunakan untuk mening-katkan objektifitas para penginterpretasi dalam menginterpretasi tes DAP.

\section{Metode}

Penelitian ini menggunakan desain penelitian kuantitatif dengan beberapa tahapan. Pada tahap pertama, peneliti mengumpulkan data yang diperoleh dari partisipan tes seleksi kerja di suatu pusat layanan psikologi, berupa hasil tes grafis dan tes 16 PF. Data tes grafis kemudian diinterpretasi oleh 2 orang psikolog dengan menggunakan skala diferensial semantik yang mengukur masing-masing dimensi pada tes DAP. Hasil interpretasi ini kemudian diuji reliabilitasnya dengan cara mengorelasikan skor dari psikolog pertama dengan skor psikolog kedua. Dimensi tes DAP yang memiliki reliabilitas rendah digugurkan, kemudian skor dari dimensi yang tidak gugur dikorelasikan dengan skor dari setiap faktor pada tes $16 \mathrm{PF}$.

\section{Subjek penelitian}

Sampel dalam penelitian ini melibatkan data 200 orang yang mengikuti seleksi kerja. Data tersebut berasal dari sebuah pusat layanan psikologi Yogyakarta. Kesamaan keadaan subjek tersebut dimaksudkan agar ada keseragaman keadaan tekanan pada subjek yang sedang mengerjakan tes DAP dan 16PF sehingga diharapkan bisa mengurangi variabel lain yang mempengaruhi hasil tes dan menghasilkan data yang dapat digunakan sebagai standar.

\section{Metode pengumpulan data}

Metode pengumpulan data yang digunakan dalam penelitian ini yaitu metode dokumentasi dan metode skala. Metode data arsip dapat diperoleh melalui catatan atau dokumen yang mencatat aktivitas individu, institusi, pemerintah, dan kelompok-kelompok lainnya. Dokumen- 
dokumen yang ada dipelajari untuk memperoleh data dan informasi dalam penelitian ini, yaitu berupa data tes DAP dan 16 PF pada 200 subjek dari suatu Biro Psikologi di Yogyakarta.

Penilaian dimensi pada DAP dilakukan dengan menggunakan skala diferensial semantik yang disusun oleh peneliti. Skala yang digunakan terdiri dari serangkaian kata sifat yang dapat menunjukkan karakteristik stimulus yang disajikan kepada sampel. Apabila serangkaian kata sifat yang menunjukkan karakteristik stimulus atau objek sikap telah dipilih dan ditentukan, maka objek sikap disajikan sebagai stimulus tungggal

1. Berdasarkan eksekusi (ukuran figur)

a. Penempatan gambar Sangat bawah

$\begin{array}{lllllll}1 & 2 & 3 & 4 & 5 & 6 & 7\end{array}$

b. Ukuran figur

Sangat kecil

$\begin{array}{lllllll}1 & 2 & 3 & 4 & 5 & 6 & 7\end{array}$

2. Berdasarkan fungsional

a. Kepala

Sangat kecil

1

2

b. Mata pada setiap rangkaian, kemudian diikuti kontinum-kontinum psikologis dimana kedua kutubnya berisi kata sifat yang berlawanan. Kata sifat yang berlawanan ini meliputi kata sifat yang favorable dan kata sifat yang tidak favorable (unfavorable) (Azwar, 1997). Pada penelitian ini, peneliti menggunakan skala yang menyediakan pilihan jawaban dengan skor 1-7. Dimana angka 1 memiliki nilai yang paling rendah dan angka 7 memiliki nilai yang paling tinggi dari masing-masing pernyataan. Beberapa contoh dimensi yang digunakan dalam skala, antara lain:
Sangat atas

7
Sangat besar

7
7 7 


\section{Metode analisis data}

Analisis data yang digunakan dalam penelitian ini adalah analisis data kuantitatif. Data DAP yang diperoleh dari skala diferensial semantik yang dikerjakan oleh dua orang psikolog. Selanjutnya data dari kedua psikolog dicari reliabilitasnya menggunakan analisis korelasi. Setelah diketahui reliabilitasnya, peneliti menjumlahkan skor dari data yang dihasilkan dua orang psikolog. Jumlah ini akan diolah menggunakan Analisis faktor terlebih dahulu untuk mengeksplorasi dimensidimensi dalam tes DAP. Setelah selesai tahap yang pertama, kemudian akan menghasilkan kumpulan - kumpulan dimensi yang saling terkait satu sama lain. Dimensi yang saling terkait tersebut kemudian akan dikore-lasikan dengan data masing-masing Faktor 16 PF. Peneliti menggunakan analisis regresi untuk melihat kumpulan-kumpulan dimensi mana yang berkorelasi dengan Faktor-faktor 16 $\mathrm{PF}$, dan dengan mempertimbangkan nilai korelasi terbesar dari setiap dimensi. Peneliti menggunakan program SPSS version 17.00 untuk melakukan proses analisis tersebut.

\section{Hasil}

\section{Reliabilitas inter-rater}

Pada tahap ini peneliti mencari reliabilitas dari penilaian dimensi yang diberikan oleh dua psikolog. Pencarian reliabilitas ini bertujuan untuk melihat apakah nilai dimensi yang diberikan oleh dua psikolog tersebut memiliki keajegan. Usaha peneliti untuk mencari reliabilitas tersebut adalah dengan cara mengorelasikan jawaban dari dua psikolog yang memberikan penilaian pada dimensi:

Tabel 1. Nilai Korelasi Penilaian Dimensi DAP oleh Psikolog

\begin{tabular}{cll}
\hline No. & \multicolumn{1}{c}{ Dimensi } & Nilai \\
\hline 1. & Penempatan gambar sangat kiri - sangat kanan & 0,660 \\
2. & Penempatan gambar sangat bawah - sangat atas & 0,719 \\
3. & Ukuran figur sangat kecil - sangat besar & 0,789 \\
4. & Tipe garis sangat samar-samar - sangat jelas & $\mathbf{0 , 1 5 4}$ \\
5. & Tipe garis satu garis - garis bertumpuk & 0,347 \\
6. & Tipe garis terputus-putus - menyambung & 0,627 \\
7. & Hapusan sangat sedikit - sangat banyak & 0,335 \\
8. Shading sangat lemah - sangat kuat & $\mathbf{0 , 1 6 7}$ \\
9. Kepala sangat kecil - sangat besar & 0,537 \\
10. Rambut sangat kurang - rambut dilebihkan & 0,716 \\
11. Rambut sangat berantakan - sangat rapi & 0,581 \\
12. Rambut sangat berombak - sangat lurus & 0,505 \\
13. Rambut semakin tidak ditutupi - semakin ditutupi & $\mathbf{0 , 0 3 1}$ \\
\hline
\end{tabular}




\begin{tabular}{|c|c|c|}
\hline No. & Dimensi & Nilai \\
\hline 14. & Alis sangat pendek - sangat panjang & 0,673 \\
\hline & Alis sangat berantakan - sangat rapi & 0,717 \\
\hline & Mata tertutup - terbuka & 0,716 \\
\hline 17. & Lingkaran mata makin kecil - lingkaran mata makin besar & 0,682 \\
\hline 18. & Telinga semakin tidak jelas - semakin jelas & 0,766 \\
\hline & Telinga sangat kecil - sangat besar & 0,806 \\
\hline & Hidung sangat pendek - sangat panjang & 0,775 \\
\hline & Hidung sangat kecil - sangat besar & 0,698 \\
\hline & Mulut semakin tidak jelas - semakin jelas & 0,543 \\
\hline & Mulut semakin tertutup - semakin terbuka & $-0,337$ \\
\hline & Leher semakin tidak jelas - semakin jelas & 0,710 \\
\hline & Leher sangat kecil - sangat besar & 0,661 \\
\hline & Leher sangat pendek - sangat panjang & 0,739 \\
\hline & Lengan sangat pendek - sangat panjang & $-0,029$ \\
\hline 28. & Lengan menjauhi tubuh - mendekati tubuh & 0,662 \\
\hline 29. & Tangan sangat kabur - sangat jelas & 0,536 \\
\hline 30. & Tangan sangat kecil - sangat besar & 0,583 \\
\hline 31. & Jari tangan sangat pendek - sangat panjang & 0,739 \\
\hline 32. & Jari tangan tumpul - sangat runcing & 0,715 \\
\hline & Kaki sangat kecil - sangat besar & 0,352 \\
\hline 34. & Kaki sangat pendek - sangat panjang & 0,573 \\
\hline 35. & Jari kaki semakin tidak jelas - semakin jelas & 0,794 \\
\hline
\end{tabular}

Dari 35 dimensi tersebut terdapat 5 dimensi yang tergolong memiliki reliabilitas di bawah 0,3 dan tidak digunakan, antara lain tipe garis sangat samar-samar - sangat jelas $(0,154)$, shading sangat lemah - sangat kuat $(0,167)$, rambut semakin tidak ditutupi - semakin ditutupi $(0,031)$, mulut semakin tertutup - semakin terbuka $(-0,337)$, dan lengan sangat pendek - sangat panjang ($0,029)$.

\section{Analisis faktor}

Setelah peneliti mempertimbangkan reliabilitas, 30 dimensi digunakan untuk analisis selanjutnya. Dimensi ini tergolong dimensi yang baik dan masih dapat digunakan untuk analasis selanjutnya. Dari 30 dimensi yang ada pada DAP, peneliti menemukan 8 faktor. Faktor-faktor DAP ini didapatkan peneliti berdasarkan tahap analisis dengan melihat hasil screen plot, percentage of varian criterion pada masingmasing dimensi DAP, dan melihat percentage of varian criterion pada masingmasing dimensi DAP. 
Tabel 2. Faktor Draw-A-Person (DAP)

\begin{tabular}{|c|c|}
\hline Faktor & Dimensi Draw-A-Person (DAP) \\
\hline Faktor I & $\begin{array}{l}\text { Tangan kabur - jelas }(\mathbf{0 , 6 8 1}), \\
\text { jari tangan pendek - panjang }(\mathbf{0 , 9 0 2 )}, \\
\text { jari tangan tumpul - runcing }(\mathbf{0 , 9 1 1 )}\end{array}$ \\
\hline Faktor II & $\begin{array}{l}\text { Leher tidak jelas - jelas }(\mathbf{0 , 8 6 6 )} \\
\text { leher kecil - besar }(\mathbf{0 , 7 8 4 )} \\
\text { leher pendek - panjang }(\mathbf{0 , 9 1 7 )}\end{array}$ \\
\hline Faktor III & $\begin{array}{l}\text { Penempatan gambar kanan - kiri }(\mathbf{0 , 5 2 4 )} \\
\text { kepala besar - kecil }(\mathbf{0 -}, \mathbf{5 7 6}) \text {, } \\
\text { tangan kecil - besar }(\mathbf{0 , 3 7 6 )} \\
\text { kaki kecil - besar }(\mathbf{0 , 8 3 3 )} \\
\text { kaki pendek - panjang }(\mathbf{0 , 7 0 0 )}\end{array}$ \\
\hline Faktor IV & $\begin{array}{l}\text { Rambut kurang - lebih } \mathbf{( 0 , 6 4 4 ) ,} \\
\text { rambut berantakan - rapi }(\mathbf{0 , 6 7 0 )} \\
\text { rambut berombak - lurus }(\mathbf{0 , 7 2 6 )} \\
\text { lengan menjauhi - mendekati tubuh } \mathbf{( -} \\
\mathbf{0 , 5 9 3 ) .}\end{array}$ \\
\hline Faktor V & $\begin{array}{l}\text { Ukuran figur kecil - besar }(\mathbf{0 , 3 1 3 )}, \\
\text { hapusan sedikit - banyak }(\mathbf{0 , 3 6 8 )}, \\
\text { mata tutup - buka }(\mathbf{0 , 8 4 6 )}, \\
\text { lingkar mata kecil - besar }(\mathbf{0 , 8 0 4 )} \text {, } \\
\text { mulut tidak jekas - jelas }(\mathbf{0 , 4 7 6 )}\end{array}$ \\
\hline Faktor VI & $\begin{array}{l}\text { Tipe garis terputus - menyambung }(\mathbf{0 , 2 5 2 )} \text {, } \\
\text { telinga tidak jelas - jelas }(\mathbf{0 , 8 4 1 )}, \\
\text { telinga kecil - besar }(\mathbf{0 , 8 2 2})\end{array}$ \\
\hline Faktor VII & $\begin{array}{l}\text { Alis pendek - panjang }(\mathbf{0 , 8 5 6 )}, \\
\text { alis berantakan - rapi }(\mathbf{0 , 8 3 0 ) ,} \\
\text { jari kaki tidak jelas - jelas }(\mathbf{0 , 2 6 5 )}\end{array}$ \\
\hline Faktor VIII & $\begin{array}{l}\text { Penempatan gambar bawah - atas }(\mathbf{- 0 , 1 5 2 )} \text {, } \\
\text { tipe garis tunggal - tumpuk }(\mathbf{0 , 1 8 4 )} \\
\text { hidung pendek - panjang }(\mathbf{0 , 8 7 1 )} \\
\text { hidung kecil - besar }(\mathbf{0 , 8 8 1 )}\end{array}$ \\
\hline
\end{tabular}

\section{Hasil Regresi}

Dari delapan Faktor DAP hanya ada dua faktor yang berkorelasi signifikan dengan Faktor 16 PF. Faktor VII memiliki hubungan yang signifikan berarti mampu memprediksi Faktor $Q_{3}(B=0,069, T=$ 2,758, p = 0,006) dan Faktor I memiliki hubungan yang signifikan berarti mampu memprediksi Faktor $\mathrm{Q}_{4}(\mathrm{~B}=-0,061, \mathrm{~T}=$ -
3,513, $\mathrm{p}=$ 0,001). Hal tersebut menunjukkan bahwa ternyata dari kedelapan faktor yang ada, hanya dua faktor saja yang mampu menjadi prediktor.

\section{Pembahasan}

Faktor $\mathrm{Q}_{3}$ memiliki $\mathrm{p}=0,050$, hal ini memasuki kriteria taraf signifikansi $\mathrm{p} \leq$ 0,05. Hal ini memperlihatkan bahwa Faktor 
VII memiliki hubungan yang cukup signifikan dan cukup mampu memprediksi Faktor $\mathrm{Q}_{3}(\mathrm{~B}=0,069, \mathrm{~T}=2,758, \mathrm{p}=0,006$ ) yang memenuhi kriteria taraf signifikasi yang baru $\mathrm{p} \leq 0,006$. Beta (B) pada hubungan signifikan antara Faktor VII pada DAP dengan Faktor $Q_{3}$ pada 16 PF memiliki nilai yang positif. Hal ini memiliki arti jika nilai Faktor VII meningkat maka nilai Faktor $\mathrm{Q}_{3}$ juga meningkat, begitu pula jika nilai Faktor VII menurun maka nilai Faktor $\mathrm{Q}_{3}$ juga menurun. Berdasarkan pernyataan tersebut, dapat dikatakan jika dimensi Faktor VII pada DAP, yaitu semakin panjang gambar alis, semakin rapi gambar alis, semakin jelas gambar jari kaki maka dapat memprediksi Faktor $\mathrm{Q}_{3}$ pada $16 \mathrm{PF}$, yaitu kontrol diri yang dimiliki seseorang semakin baik, seseorang semakin terbuka pada peraturan sosial yang ada di sekitarnya, semakin tekun, semakin memiliki pemikiran pada masa depan, memiliki perhatian pada orang lain, dan memiliki ketelitian. Begitupun sebaliknya, semakin pendek gambar alis, semakin berantakan gambar alis, dan semakin tidak jelas gambar jari kaki, maka dapat memprediksi Faktor $\mathrm{Q}_{3}$ pada $16 \mathrm{PF}$, yaitu seseorang yang memiliki kontrol diri yang kurang baik, seseorang semakin tertutup pada peraturan sosial yang ada di sekitarnya, semakin kurang tekun, kurang memiliki pemikiran pada masa depan, kurang memiliki perhatian pada orang lain, dan kurang memiliki ketelitian.
Faktor $\mathrm{Q}_{4}$ memiliki $\mathrm{p}=0,006$, hal ini memasuki kriteria taraf signifikansi $\mathrm{p} \leq$ 0,05. Hal ini memperlihatkan bahwa Faktor I memiliki hubungan yang signifikan dan cukup mampu memprediksi Faktor $\mathrm{Q}_{4}(\mathrm{~B}=$ $0,061, \quad \mathrm{~T}=-3,513, \mathrm{p}=0,001)$ yang memenuhi kriteria taraf signifikasi yang baru $\mathrm{p} \leq 0,006$. Beta (B) pada hubungan signifikan antara Faktor I pada DAP dan Faktor $\mathrm{Q}_{4}$ pada $16 \mathrm{PF}$ memiliki nilai yang negatif. Hal ini memiliki arti jika nilai Faktor I meningkat maka nilai Faktor $\mathrm{Q}_{4}$ menurun, begitupun jika nilai Faktor I menurun maka nilai Faktor $\mathrm{Q}_{4}$ meningkat. Berdasarkan pernyataan tersebut, dapat dikatakan juga jika dimensi Faktor I pada DAP, yaitu penempatan gambar makin ke bawah, tipe garis semakin bertumpuk, semakin panjang gambar hidung, semakin besar gambar hidung, maka dapat memprediksi Faktor $\mathrm{Q}_{4}$ pada $16 \mathrm{PF}$, yaitu seseorang kurang cekatan dalam melakukan suatu kegiatan, seseorang kurang memiliki perilaku dalam hal pencegahan terhadap suatu hal, kecenderungan kurang suka bertingkah, dan kecenderungan orang yang tidak mudah lelah. Begitupun sebaliknya, gambar lengan semakin menjauhi tubuh, semakin kabur gambar tangan, semakin pendek gambar jari tangan, semakin tumpul gambar jari tangan, semakin samar tipe garis dalam gambar, dan semakin terbuka gambar mulut, maka dapat memprediksi Faktor $\mathrm{Q}_{4}$ pada 16 PF yaitu seseorang cekatan dalam melakukan suatu kegiatan, 
seseorang memiliki perilaku dalam hal pencegahan terhadap suatu hal, kecenderungan suka bertingkah, dan kecenderungan orang yang mudah lelah.

Faktor VII dan Faktor $\mathrm{Q}_{3}$ memiliki $\mathrm{R}^{2}=0,07$ dengan sumbangan efektif Faktor VII pada Faktor $\mathrm{Q}_{3}$ sebesar 7\%. Hal ini juga memiliki arti bahwa sebanyak 93\% variasi Faktor $\mathrm{Q}_{3}$ mengikuti variasi variabel lain. Selanjutnya Faktor I dan Faktor $\mathrm{Q}_{4}$ memiliki $\mathrm{R}^{2}=0,106$ dengan sumbang efektif Faktor I pada Faktor $\mathrm{Q}_{4}$ sebesar 10,6\%. Hal ini juga memiliki arti bahwa sebanyak 89,4\% variasi Faktor $\mathrm{Q}_{4}$ mengikuti variabel lain. Dari paparan di atas, dapat disimpulkan hubungan antara DAP dan 16 PF tampak sangat lemah.

Jumlah faktor yang digunakan baik yang belum maupun yang sudah mempertimbangkan reliabililitas tergolong terlalu banyak. Hal ini dikarenakan korelasi antar dimensi yang cenderung kecil. Terjadinya korelasi yang kecil antar dimensi DAP ini dapat disebabkan beberapa hal. Peneliti menduga penyebabnya antara lain :

a. Proses menggambar atribut-atribut kepribadian yang berbeda secara kualitatif. Hal ini memiliki pengertian bahwa tiap-tiap dimensi DAP akan memiliki prediksi konstruk yang berbeda. Misalnya: gambar tekanan mata dalam DAP dapat mengukur variabel $\mathrm{A}$, sedangkan gambar tangan dapat mengukur variabel B. Banyaknya perbedaan DAP dalam memprediksi konstruk akan memperkecil hubungan signifikan antar dimensi DAP.

b. Adanya kemungkinan variabel lain yang mempengaruhi responden dalam menggambar DAP. Secara teori, hasil gambaran seseorang merupakan hasil proyeksi dari pribadi dirinya yang memiliki hubungan erat dengan impulsimpuls, kecemasan, konflik-konflik, dan ciri-ciri kompensatoris individu yang bersangkutan. Berdasarkan penelitian ini, peneliti menduga bahwa mungkin gambar yang dibuat oleh seseorang tidak hanya memproyeksikan dirinya melainkan bisa mengungkap variabel yang lain (Machover, 1965). Misalnya saja, dari hasil gambar dapat dilihat tingkat intelegensi responden tersebut. Ini berarti hasil gambaran responden merupakan pengaruh tingkat intelegensi yang dimiliki responden.

\section{Simpulan}

Berdasarkan hasil penelitian dan pembahasan yang telah diuraikan sebelumnya, maka dapat disimpulkan bahwa antara Faktor 16 PF dan Faktor Draw-A-Person (DAP) didapatkan dua Faktor Draw-A-Person (DAP) yang dapat digunakan untuk memprediksi beberapa Faktor $16 \mathrm{PF}$. Faktor tersebut antara lain: Faktor VII dengan Faktor $\mathrm{Q}_{3}$ dan Faktor I dengan Faktor $\mathrm{Q}_{4}$. 


\section{Saran}

Dari hasil analisis faktor dan analisis regresi, ada beberapa dimensi Draw-APerson (DAP) yang dapat diprediksi oleh Faktor 16 PF. Pengguna atau penginterpretasi Draw-A-Person (DAP) sebaiknya mempertimbangkan dimensi yang dapat diprediksi sebagai dimensi valid yang dapat digunakan untuk menginterpretasi tes Draw-A-Person (DAP). Hal ini juga bisa dilakukan dengan cara penginterpretasi menggunakan tes kepribadian lain yang lebih valid untuk mendampingi interpretasi tes Grafis.

Saran untuk peneliti selanjutnya adalah, berdasarkan beberapa kelemahan penelitian yang telah diuraikan pada bab sebelumnya, peneliti selanjutnya dapat menambahkan jumlah sampel, sehingga sampel yang digunakan untuk analisis dapat ideal. Peneliti selanjutnya juga bisa menambahkan dimensi DAP yang belum digunakan dalam penelitian ini. Kemudian, peneliti selanjutnya bisa juga mengorelasikan tes DAP dengan menggunakan tes Kepribadian lain yang mengungkap aspek yang berbeda dari atribut dari 16 PF. Peneliti selanjutnya juga dapat menggunakan teknik-teknik yang lain untuk mendapatkan faktor-faktor yang lebih objektif dari dimensi yang telah ditemukan oleh Machover, misalnya menggunakan Multi Dimentional Scale (MDS).

\section{Daftar Pustaka}

Agnes, I. E. (2010). Pendapat tentang Draw-APerson (DAP) (Rekaman Seluler). Yogyakarta: Fakultas psikologi Universitas Sanata Dharma.

Azwar, S. (1997). Reliabilitas dan validitas. Yogyakarta: Pustaka Pelajar.

Boyle, G. J. (1989). Re-examination of the major personality factors in the Cattel, Comrey, and Eysenck scales: Were the factor solutions of Noller et al. optimal? Personality and Individual Differences, 10(12), 12891299.

(2004). 16 PF: Personality. Sage Benchmarks in Psychology

Carnivez, G. L., \& Allen, T. J. (2005). Convergent and factorial validity of the 16 PF anf the NEO-PI-R. Naskah dipresentasikan pada pada Konvensi Tahunan American Psychological Association, Washington, DC.

Cattell, H. E. P. (1996). The original big five: A historical perspective. European Review of Applied Psychology, 46(1), 5-14.

Cattel, R. B. (1975). Personality and motivation structure and measurement. New York: Harcourt, Brace and World.

(1973). Personality and mood by questionnaire. San Fransisco: JosseyBass.

Cattel, R. B., Eber, H. W., \& Tatsuoka, M. M. (1970). Handbook for the sixteen personality factor questionnaire. Champaign, Illinois: Institute for Personality and Ability Testing.

Conn, S. R. \& Rieke, M. L. (1994). The 16 PF fifth edition technical manual. Champaign, Illinois: Institute for Personality and Ability Testing. 
Dancer, L. J., \& Woods, S. A. (2007). Higherorder factor sructures and intercorelations of $16 \mathrm{PF}$ and FIROB. International Journal of Selection and Assessment, 14(4), 385-391.

Edwin A., \& Bellak L. (1950). Projective psychology. New York: Grove Presss Inc.

Gerbing, D. W., \& Tuley, M. R. (1991). The 16 PF related to the five-factor model of personality: Multiple-indicator measurement versus the a priori scales. Multivariate Behavioral Research, 26(2), 271-289.

Groth-Marnat, G., \& Roberts, L. (1998). Human figure drawings and house-treePerson drawings as indicators of self-esteem: A quantitative approach. Journal of Clinical Psychology, 54, 219-222.

Hooker, K., \& McAdams, P. (2003). Personality reconsidered: A new agenda for aging research. Journal of Gerontology, 6, 296 - 304.

Machover, K. (1965). Personality projection in the drawing of the human figure: $A$ methode of personality investigation, sixth edition, springfield, thomas. (Terjemahan Hanna Widjaja), UPT Fakultas Psikologi Universitas Padjajaran. 